\title{
Research on the Development of Green Intercity Logistics System under the Multi-zone Overlap in Fujian Province
}

\author{
Qi Jiang ${ }^{1, *}$, Jie Shi ${ }^{2}$ \\ ${ }^{1}$ School of Economics and Management, Fuzhou University of International Studies and Trade, 28 \\ Yuhuan Road, Fuzhou Changle City,Fujian Province, China \\ ${ }^{2}$ Flight Department, Xiamen Airline CO.LTD, 22 Dailiao Road, Huli District, Xiamen City, Fujian \\ Province, China \\ 2321665092@qq.com, shijiea0202@163.com
}

Keywords: multi-zone overlap, green logistics, intercity logistics, the mode of transportation

Abstract: The paper aims at providing development strategies of building a green and efficient intercity logistics system in Fujian province of China.By changing the existing port transport mode that relied heavily on road transport system, Fujian province will not only has diversified mode of transportation, also will implement the national sustainable development strategy and the "The 13th five-year plan for the development of a modern comprehensive transportation system". The research results will include suggestions for China (Fujian) Free Trade Zone, core zone of Maritime Silk Road, Ecological Civilization Experimental Zone and Innovation Demonstration Zone. And it will also contain suggestions for the future construction of a modernized comprehensive transportation hub for reference by relevant decision-making departments.

\section{Multi-Zone Overlap Introduction}

Since December 2014, China State Council has continuously approved the establishment of China (Fujian) Free Trade Zone, core zone of Maritime Silk Road, Ecological Civilization Experimental Zone and Innovation Demonstration Zone. Fujian province is in a strategic opportunity period of "multi-zone overlap".

First of all, China (Fujian) Free Trade Zone takes "open to Taiwan" and "comprehensive partnership" as the direction, and it should give full play to build legalized, international and market-oriented business environment to set an example for the whole nation.

Secondly, the government has positioned Fujian province as the core area of the 21st Century Maritime Silk Road aiming to speed up industrial upgrading. And then, it will take the initiative to promote cooperation with the regions along the Maritime Silk Route, which will deeps the role of leading, demonstrating, gathering and radiating. Besides, the government requires Fujian province to strengthen cross-provincial and regional cooperation and become the one of the leader city on "One Belt And One Road" region. Besides, Fujian should strengthen interaction with Hong Kong, Macao and Taiwan and carry forward the construction of "the silk". Moreover, cooperation in hightech areas are urgent. 
Thirdly, according to national strategies, Fujian Ecological Civilization Experimental Zone is positioned in four areas: the pilot zone for the scientific development of land and space, the pilot zone for the realization of ecological product value, the demonstration zone for the reform of environmental governance system, and the practice zone for the evaluation of green development. In this regard, Fujian province will take the new development concept as the guidance, and make great efforts in mechanism innovation to keep balance of the ecological environment and the economic development.

Finally, in 2016, the State Council officially approved the Innovation Demonstration Zone in Fuzhou, Xiamen and Quanzhou cities in an effort to create new regional economic growth poles. Through strengthening efforts to build national innovation demonstration zone and accelerating the construction of high-level major scientific research institutions, the science and technology innovation center which has strong industry competitiveness and international influence will be created.

With the support of national strategies, Fujian province is in the opportunity period of rapid development. Especially for the intercity logistics system, the economic development and the emphasis on environment will bring great changes to the intercity logistics system in Fujian province. Greening and intensification will be the theme of the development of intercity logistics in the next stage.

\section{Fujian intercity logistics status and green concept}

\subsection{Fujian Intercity Logistics Status}

Intercity logistics is an important form of social logistics,which refers to the mode of logistics transportation between cities(Bin Zhang, 2015). Owing to the natural advantages,Fujian province has gradually developed port economy, forming a supply city with Fuzhou, Xiamen as the central city, and Putian, Ningde, Quanzhou, Sanming and other places as the supply hinterland to promote regional development. In terms of intercity logistics, different from other cities with high proportion of highway transportation, the waterway freight transportation turnover in Fujian accounts for about $80 \%$ of the total. According to statistics, the cargo turnover of Fujian province in 2016 reached 607.483 billion tons, among which the waterway, highway, railway and air transport were 4846.44, 1094.7, 129.45 and 424 million tons, accounting for about $80 \%, 18 \%, 2 \%$ and $0.001 \%$ respectively.

Although in recent years, relying on the port advantages of Xiamen port and Fuzhou port, Fujian province has made great efforts to develop port logistics, vigorously build port collection and transportation channels, and expand the hinterland of supply of goods. However, compared with other port cities in China, the port collection and transportation development in Fujian province is relatively insufficient, and the development mode of intercity logistics needs to be optimized.

First of all, it is limited to some factors like small businesses in Fujian province and family workshops enterprises that most customers frequently yet slightly using road transport.Therefore, it formed a "small, scattered and disorderly" development model, lacking of freight station to transfer goods.All in all,the pattern cannot achieve economies of scale and promote the competitiveness of the regional inter-city logistics.

Secondly, Fujian province has a single mode of inter-city logistics transportation, with water transportation accounting for the majority. Due to water transportation transporting goods through the waterway, influenced by natural conditions, its operating range is restricted. If there is no natural channel cannot transport, so inland cities lacking of waterways, in the current less share of railway transportation, only could develop small-scale highway transportation through the limited channel, cannot enjoying the dividends of the waterways. These inland cities are the weakest link in regional development and the bottleneck that needs to be broken. 
Thirdly, the current regional intercity logistics mode in Fujian province is basically based on transportation, with few value-added services such as warehousing, bonded goods, processing, entrepot trade, etc., and the service quality in transportation is also poor, and goods are often damaged and poor.

\subsection{Green Logistics Concept}

Green logistics refers to the realization of the purification of logistics environment and the maximum utilization of logistics resources while restraining the harm of logistics to the environment. The connotation of green logistics includes five aspects such as intensive resources, green transportation, green storage, green packaging and waste logistics, among which intensive resources are the essential content of green logistics and one of the main guiding thoughts of the development of logistics industry.

Green logistics encourages intensive transportation of large volume, avoids scattered transportation. It is in the hope of creating a pattern in which waterway transportation is superior, railway is secondary and highway is auxiliary. Under the current situation, both Xiamen port and Fuzhou port are continuously improving their port handling capacity and service capacity to stride forward to a world-class port. Under this situation, the import and export freight volume is bound to increase rapidly, which will force the reform of Fujian intercity logistics transportation mode towards a more green and intensive direction. Taking Fuzhou port as an example, under the pressure of the accelerated increase of freight volume, Fuzhou port began to develop new multimodal transport businesses, such as sea-railway transit, to accelerate the establishment of a faster and more green intercity logistics system. Up to now, four sea-railway lines (including cold chain container lines) have been opened in Jiangyin port area of Fuzhou port, and the annual volume of sea rail container has increased from 80 TEU in 2014 to 20975 TEU in 2017. The total cargo volume in the first half of 2018 has reached 18109 TEU, up 112.6 percent year-on-year. Fuzhou port, with Jiangyin port as the core, forms a new logistics channel through sea-railway transport. The opening of the sea-railway link broke the original commonly used river and sea transport mode. At the end of 2017, the province's first cold-chain container sea-railway transit special train started its service in the Jiangyin port, opening a new mode of cold-chain logistics transportation in Fujian province. Moreover, new projects such as the "railway-sea-railway" train line and the cold-chain container seaborne express line, have achieved rapid development from scratch, providing new impetus to the port supply chain project of Jiangyin port of Fuzhou.

Generally speaking, in the process of port upgrading, under the pressure of its own development, the port and provincial and municipal governments will continue to innovate and improve the port's collection and distribution system, which will lead to the development of green intercity logistics.

\section{The influence of "multi-area OVERLAP" on Fujian's green intercity logistics}

\subsection{Favorable Measures of "Multi-Zone Overlap"for the Development of Green Intercity Logistics}

The favorable measures of "multi-zone overlap" for the development of green intercity logistics can be divided into three categories: the reform driven by the growth of transport demand, the support of policy dividend to encourage development and strategic positioning.

\subsubsection{The Growth of Transport Demand Forces Reform}

With strategic support, Fujian province achieved 683.9 billion yuan in exports in 2016, up 10.7 
percent from 2012. In 2016, foreign capital was actually utilized at $\$ 8.19$ billion, an increase of 29.2\% over 2012. In addition, policy advantages have also promoted the accelerated overseas economic and trade cooperation of a number of Chinese enterprises such as Wuyi, Zijin Mining, Fuyao Glass and Qingtuo Group. The increase of trade volume and the growth of enterprises will also bring more transportation demand, which will force the reform of Fujian's existing inter-city logistics transportation mode.

\subsubsection{Policy Dividends Encourage Development}

Among the policy dividends brought by Fujian Free Trade Zone, there are some policies and measures to encourage shipping, such as coastal shipping (Shanchun Ye, 2017) and port of departure tax rebate, so as to improve transportation services and attract more sources of goods exporting and importing from Fujian. For sea-railway joint transportation, Fujian Free Trade Zone proposes the measure of freight subsidy, and directly uses the method of economic subsidy to attract potential customers. Taking Xiamen port as an example, the government gives subsidies of 200-800 yuan per tender box to the actual operators for the import and export of goods via the sea-railway linking. At the same time, an additional subsidy of 180 yuan per tender box will be added to further supplement the shortboard of the infrastructure construction of railway combined transportation, and to solve the "last kilometer" problem of the railway transportation of Xiamen port, and to encourage the green development of intercity logistics while improving the competitiveness of the inland hinterland of Xiamen port.

\subsubsection{Support for Strategic Positioning}

The strategic positioning of Fujian Provincial Ecological Civilization Pioneer Demonstration Zone covers four aspects: land space scientific development pilot zone, green circular low-carbon development pilot zone, urban and rural residential environment construction demonstration zone, and ecological civilization system innovation experimental zone. With the support of strategic positioning, the transportation mode of intercity logistics is bound to develop towards a greener direction. At the same time, Fujian province will strive to become an important hub for the connectivity construction of the 21st Century Maritime Silk Road and build the port city of Fujian as the strategic fulcrum for maritime cooperation. Against this background, it is also in urgent need of a greener intercity logistics mode to meet the potential transportation needs.

\subsection{Direct and indirect effects}

\subsubsection{Direct Effects}

Under the function of multi-zone overlap, the supply of goods extends inland, so Fujian's supply of goods also will be a large number of growth. Inland waterway transport is limited by natural condition, and road transport intensification is too low to be unable to undertake a large number of demand, so the railroad will have a new development opportunity. Especially, the sea ports connecting with sea-railway transport will play a more important role.

In addition, the government subsidizes the customers who choose the sea-railway transport, which will directly stimulate the potential customer groups and increase the demand of sea-railway transport. Secondly, the emergence of subsidies is beneficial to the operators of the combined transport business to turn losses into profits, thereby indirectly cultivating market players and forming a healthy competition(Yudong Fang, 2013).Thirdly, the subsidy reduces the cost of the searailway transport, which is conducive to attract more inland sources.

Furthermore, the construction of Ecological Civilization Demonstration Area is conducive to 
guiding the government to put the construction of ecological civilization in a prominent position. In addition to economic development, attention should be paid to energy conservation, emission reduction and resource allocation. In the field of intercity logistics, the government will certainly implement the spirit of Ecological Civilization Demonstration Area and encourage the development of green intercity logistics. In the long run, the concept of green logistics will be widely publicized and popular.

In addition, the strategic positioning of the state to establish the Silk Core Area in Fujian province lies in taking the front port group of Fujian as the fulcrum, radiating the economic development of inland areas. Considering the transportation distance between inland regions and Fujian ports, combined with the increase in import and export brought by the policy dividend of Free Trade Zone, railway transportation will have more development prospect with its characteristics of being suitable for medium-distance transportation and green intensification.

\subsubsection{Indirect Effects}

With the deepening of the multi-zone overlap, a network transportation structure composed of several regions will be formed between the ports in Fujian province and its hinterland of supply of goods. The same region is easier to form agglomeration effect for a certain supply of goods and generate economies of scale. However, the division of labor and cooperation between different regions will become clearer and closer. In terms of transportation, the economies of scale resulting from the agglomeration effect can help to get rid of the previous "small, scattered and chaotic" pattern, forming the large volume of transportation, and promoting the development of sea and rail combined transportation and waterway transport with a higher green level.

\section{The development Suggestions}

As the waterway transport in Fujian is relatively developed, the green inter-city logistics development proposal in Fujian is mainly put forward from the aspects of railway transport and searailway combined transport.

The ports will strengthen construction of inland ports and implement tax rebates for departure terminals. Fujian province could connect with inland cities to together build railway inland port, and expand the hinterland of goods supply with policy advantages. The tax refund at the pilot departure station can be regarded as export when the export goods arrive at the inland railway port. The tax refund procedures can be handled to shorten the capital turnover, reduce the capital occupation and promote the increase of railway transport demand.

To play the comparative advantages, coastal and mountainous areas to jointly build the Sea Silk Core Areas. The coastal port cities in Fujian province should strengthen the supporting and leading role, and Quanzhou city should focus on the construction of the Sea Silk Leading Zone, while Fuzhou, Xiamen, Pingtan, Zhangzhou, Putian, Ningde and other port cities should focus on the construction of maritime cooperation strategic fulcrum. Mountain cities should give full play to the important supporting role of hinterland development along the maritime Silk Road, and take an active part in the construction of the Sea Silk Road.

To improve infrastructure and integrate CFS and ports. Fujian ports will strengthen infrastructure development, and promote seamless connectivity of the railway and ports in order to ensure smooth flow of containers importing and exporting from port docks to railway stations. Such a connection between the port area and the railway station will be greatly enhanced, which is conducive to creating a green channel for sea-railway transport (Yun Shen, 2014).

To strengthen supervision of road container lorry transportation and guide vehicles to pass in an orderly manner (Ying Zhang, 2009). Relevant departments should strengthen the management of 
the container lorry and container freight stations around the port area, and reasonably organize the collection and distribution of container lorries around the port area to ensure smooth traffic flow. In addition, we should guide the provincial market card to the suburban circular road, and form a new road for container lorries, so as to avoid the container lorry taking up the road resources of the outer road and to relieve its traffic pressure.

\section{Conclusion}

By analyzing the current situation of intercity logistics transportation in Fujian province, we point out the shortcomings of the existing mode of railway transportation, and introduce the concept of green logistics, and encourage the guidance from road transportation to railway transportation. Subsequently, policy effects affecting intercity logistics and transportation will be summarized in China (Fujian) Free Trade Zone, core zone of Maritime Silk Road, Ecological Civilization Experimental Zone and Innovation Demonstration Zone. Finally, the development Suggestions are put forward from the aspects of infrastructure construction and subsidy mechanism to provide reference for decision-making of relevant departments.

\section{References}

[1] Bin, Zhang, 2015.The analysis of typical port logistics development mode and its enlightenment to China's port logistics development, Logistics Engineering and Management. 34(12), pp.52-54.

[2] Shanchun, Ye, 2017.Research on development of coastal incidental business under the background of Free Trade Zone, Value Engineering. 31(36), pp.226-227.

[3] Ying, Zhang, 2009. The analysis of container transportation system in port, Logistics Engineering and Management. 31(3), pp.34-35.

[4] Yudong, Fang, 2013. A brief analysis of Ningbo port logistics distribution system optimization, Logistics Technology. 32(3), pp.130-132.

[5] Yun, Shen, 2014.The intelligent railway-railway transportation mode is aimed at the demand of fast, efficient and safe modern logistics, Communications Science and Technology Heilongjiang. 16(1), pp.141-142. 